\title{
Microtubule-Associated Protein Tau
}

National Cancer Institute

\section{Source}

National Cancer Institute. Microtubule-Associated Protein Tau. NCI Thesaurus. Code C75652.

Microtubule-associated protein tau (758 aa, $79 \mathrm{kDa})$ is encoded by the human MAPT gene. This protein may be involved in axon stability. 